\title{
New data on Cyclocosmia loricata (C.L. Koch, 1842) (Aranei: Halonoproctidae) with first description of the male palp
}

\author{
Новые данные о пауке Cyclocosmia loricata (C.L. Koch, 1842) \\ (Aranei: Halonoproctidae), и первое описание памьпы самџа \\ этого вида
}

\author{
Manuel de Luna ${ }^{1}$, Carlos Solîs-Rojas ${ }^{2}$, Roberto Garcîa-Barrios ${ }^{3}$, \\ Ana B. Millan ${ }^{4}$ \\ Мануэль Ае $\Lambda$ уна ${ }^{1}$, Карлос Солис-Рохас ${ }^{2}$, Роберто Гарсия-Барриос ${ }^{3}$, \\ Ана Б. Мимлан
}

1,2,3,4 Laboratorio de Entomología y Artropodos, Facultad de Ciencias Biologicas, Universidad Autónoma de Nuevo Leon campus de
Ciudad Universitaria, Pedro de Alba S/N, C.P. 66452, San Nicolas de los Garza, Nuevo Leon, Mexico.
E-mails: ${ }^{1}$ scolopendra94@gmail.com, ${ }^{2}$ csolis01@hotmail.com, ${ }^{3}$ roberto.garciab98@gmail.com ${ }^{4}$ anadulcemillan@hotmail.com

KEY WORDS: Araneae, distribution, Nuevo Leon, Tamaulipas, opisthosomal ribs, new record.

КЛЮЧЕВЫЕ СЛОВА: Araneae, распространение, Нуэво-Леон, Тамаулипас, ребра диска опистосомы, новое нахождение.

ABSTRACT: This article details new records of the trapdoor spider Cyclocosmia loricata (C.L. Koch, 1842) in Nuevo Leon and Tamaulipas states of northeast Mexico, and refutes previous records of $C$. truncata (Hentz, 1841) for Nuevo Leon. Insight in the variation in rib counts of the disc of the opisthosoma as well as the first description of the male palp are given.

How to cite this paper: De Luna M., Solís-Rojas C., García-Barrios R., Millan A.B. 2021. New data on Cyclocosmia loricata (C.L. Koch, 1842) (Aranei: Halonoproctidae) with first description of the male palp // Arthropoda Selecta. Vol.30. No.1. P.89-93. doi: 10.15298/arthsel.30.1.07

РЕЗЮМЕ: Статья описывает новые находки мигаломорфа Cyclocosmia loricata (C.L. Koch, 1842) в северной части Мексики на территории штатов Нуэво-Леон и Тамаулипас и опровергает предшествующие указания C. truncata (Hentz, 1841) для штата Нуэво-Леон. Приведены анализ вариантов числа радиальных ребер диска опистосомы, а также первое описание пальпы самца исследуемого вида.

\section{Introduction}

The Halonoproctidae Pocock, 1901 is a recently elevated family of trapdoor spiders [Godwin et al., 2018] which includes 94 species placed in six genera distributed in all zoogeographical realms [Godwin et al., 2018; World Spider Catalog, 2020].

Among the genera which make up this family, $C y$ clocosmia Ausserer, 1871 stands out due to its peculiar sclerotized opisthosoma. This genus is currently com- prised by ten species, seven from southeast Asia and three from North America. The North American representatives of this genus are Cyclocosmia loricata (C.L. Koch, 1842) from Mexico, Cyclocosmia torreya Gertsch et Platnick, 1975 from the USA, and Cyclocosmia truncata (Hentz, 1841) also from the USA [World Spider Catalog, 2020].

Materials and methods

All the material revised is deposited in the Coleccion Aracnologica of the Facultad de Ciencias Biologicas of the Universidad Autonoma de Nuevo Leon. The prefix of all the samples analyzed is "FCB-AMYGA"; this is the code used in the collection to label all mygalomorph spider samples excluding those in the family Theraphosidae. The samples were analyzed using an AmScope SM-1TSZ stereomicroscope and photographed using an AmScope MU1603 microscope digital camera. All measurements are given in $\mathrm{mm}$. The map in Fig. 4 was created with http:simplemappr.net. The ribs of the disc of the opisthosoma were counted following the method described by Gertsch \& Platnick [1975] and Schwendinger [2005].

\section{Taxonomy}

Family Halonoproctidae Pocock, 1901

Genus Cyclocosmia Ausserer, 1871

NOTES. This genus differs from the rest of halonoproctid trapdoor spiders by having a truncated, ribbed and highly 


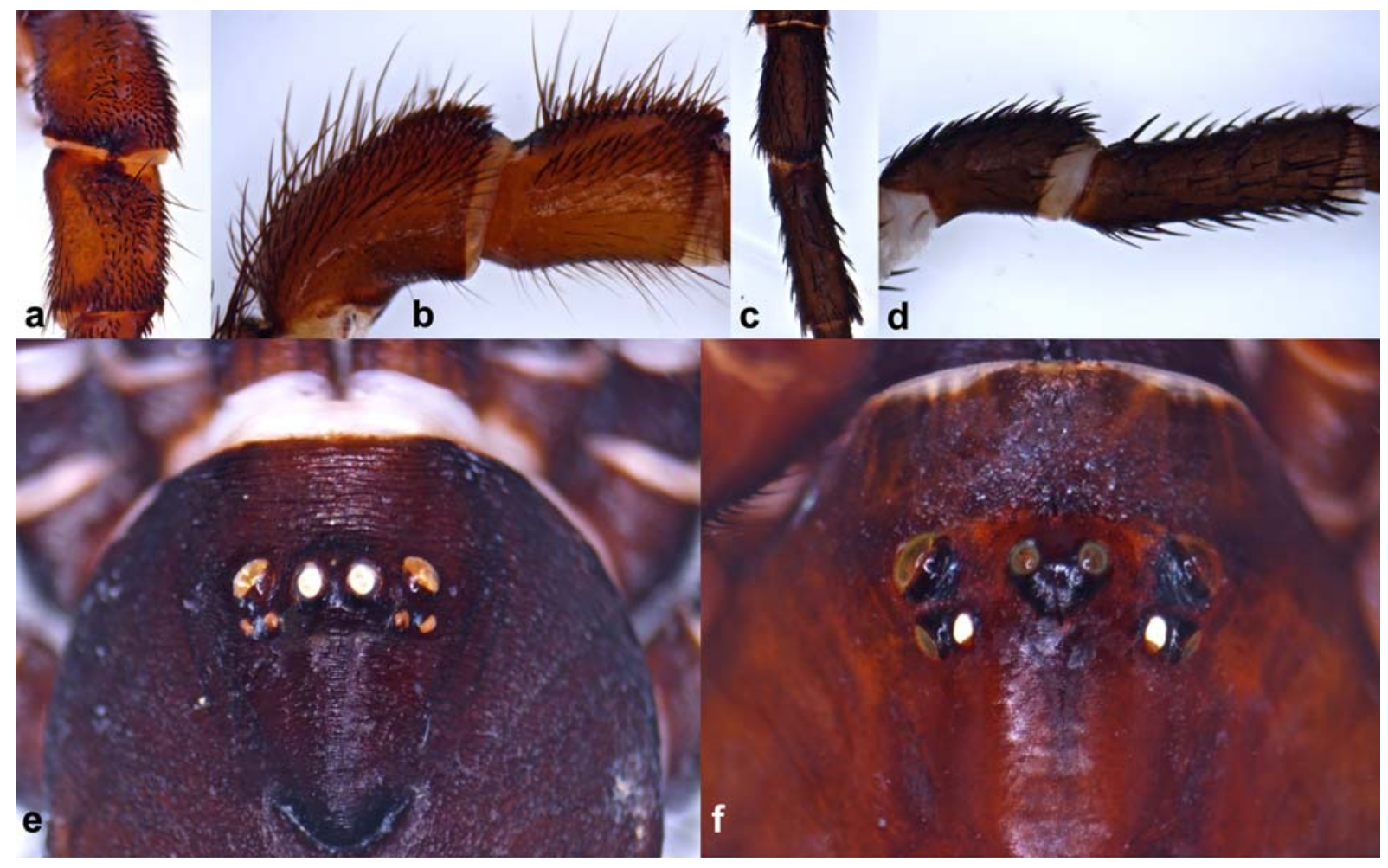

Fig. 1. Cyclocosmia loricata: a — female \#034, patella and tibia of left leg III, dorsal view; b — same, lateral; c - male \#035, patella and tibia of left leg III, dorsal; d - same, lateral; e - male \#035, eye arrangement, dorsal; f — same for female \#034.

Рис 1. Cyclocosmia loricata: a — самка \#034, колено и голень левой ноги III, вид сверху; b — то же, сбоку; с - самец \#035, колено и голень левой ноги III, вид сверху; d - то же, сбоку; е - самец \#035, расположение глаз, сверху; $\mathrm{f}$ - то же для самки \#034.

sclerotized opistosoma [Gertsch, Platnick, 1975; Xu et al., 2017]. Genera which have similar modificationsin the opisthosoma (although to a lesser degree) are Galeosoma Purcell, 1903 from Africa and IdiosomaAusserer, 1871 from Australia, both which belong to the trapdoor spider family Idiopidae Simon, 1889; they differ from Cyclocosmia in the eyes which are arranged in three rows, unlike those of $C y$ clocosmia which are arranged in two [Schwendinger, 2005; $\mathrm{Xu}$ et al., 2017]. This genus is comprised by ten species, three which are found in America (Mexico and USA) and seven found in Asia (China, Laos, Thailand and Vietnam) [WSC, 2019].

\section{Cyclocosmia loricata (C.L. Koch, 1842) Figs 1a-f, 2c-i, 3a-h.}

Actinopus loricatus C.L. Koch, 1842: 99, f. 752 ().

Chorizops loricatus: Ausserer, 1871: 144; Simon, 1897: 172 f. 1-3; Petrunkevitch, 1909: 251, f. 1-2 (); Gertsch, Wallace, 1936: 12, f. 13 (†).

Cyclocosmia loricata: Gertsch, Platnick, 1975: 15, f. 27, 30$31,35\left(\sigma^{7}+\right)$

MATERIAL EXAMINED. MeXico: Nuevo Leon: $032-1$ juv., Escobedo, Cerro del Topo Chico, 27.I.2008 (J. Chavez); 034 - 1 , Galeana, Cerro el Potosí (C. Solís-Rojas); $035-1 \sigma^{7}$, Guadalupe, Cascadas del Cerro de la Silla, 16.IV.2008 (A. Samhas); $037-1 \sigma^{7}$, Llano la Soledad, 27.V.2007 (N. Ruíz); $219-1$ juv., Escobedo, Cerro del Topo Chico, 20.VII.2018 (B. González); 250 - 1 ㅇ, Santiago, Puerto Genovevo, 15.III.2008 (C. SolísRojas); 252 - 1 juv., Guadalupe, Cascadas del Cerro de la Silla, 29.VII.1977 (M. Socorro-Escobar). Tamaulipas: $033-1$ + , Méxi- co, Tamaulipas, Altamira, Miradores, 26.VIII.1978 (A. Ramos).

DIAGNOSIS. Cyclocosmia loricata differs from all other Cyclocosmia in having a slight, glabrous, proximodorsal depression in the tibia III (Fig. 1a-d) [Gertsch, Wallace, 1936; Gertsch, Platnick, 1975]; it distinguishes itself further from $C$. torreya and $C$. truncata, the other American representatives of the genus, by possessing a wider eye arrangement which has considerable separation between the anterior median and lateral eyes (Fig. 1e-f) [Gertsch, Wallace, 1936] and by the rounded, horizontal bars in the spermathecae [Gertsch, Platnick, 1975]. It differs further from $C$. truncata in the rib angles of the disc of the opisthosoma disc which protrude in $C$. loricata. Male of $C$. truncata also possesses a prolateral ridge in the distal region of the palpal tibia (Fig. 2a-b) which is absent in C. loricata (Fig. 2c-i); the proportions of the palp are also different: in C. truncata the tibia is 2.8 times longer than the cymbium, 2.1 times longer than the bulb and the bulb is 2.3 times longer than wide (Fig. 2a-b) while in C. loricata the tibia is 3.5-3.7 times longer than the cymbium, 2.9 times longer than the bulb and the bulb is 1.9 times longer than wide (Fig. 2c-i).

MEASUREMENTS. The measurements for the adult specimens analyzed are $\mathbf{0 3 3}$ — carapace: 7.9 large/9.6 wide; 034 - carapace: 9.9 large/7.8 wide; 035 - carapace: 6.9 large/6.0 wide, palp tibia: 5.3 large, palp cymbium 1.4 large, palp bulb 1.9 large/1wide; 037 — carapace: 9.8 large/8.2 wide, palp tibia: 5.6 large, palp cymbium 1.6 large, palp bulb 1.9 large/1wide; 250 - Carapace: 7.6 large/5.9 wide.

STRUCTURES. The rib counts for the specimens analyzed are $\mathbf{0 3 2}$ - L:22/R:22 (Fig. 3a), 033 - L:17/R:15 

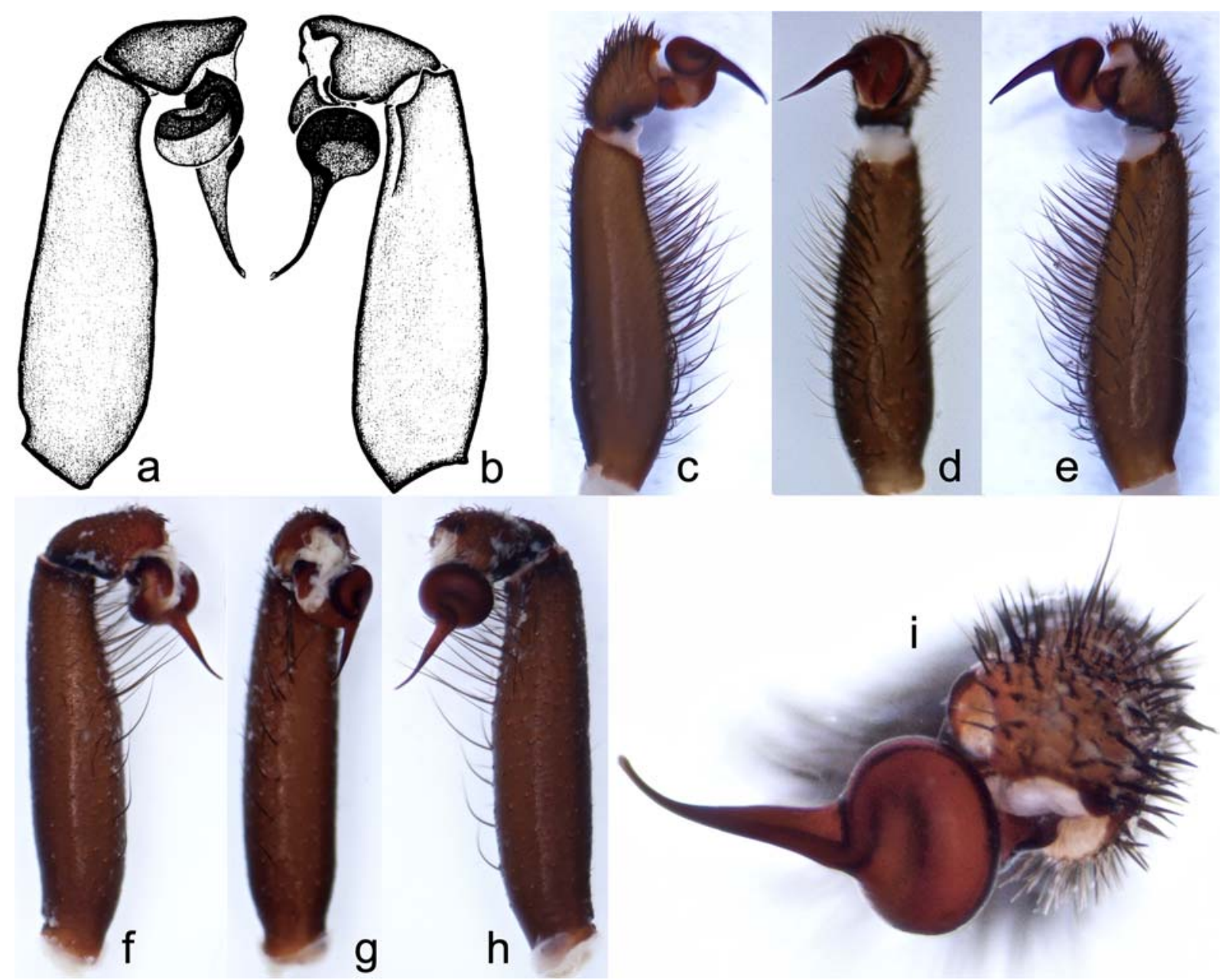

Fig. 2. Cyclocosmia spp., male palp: a - C. truncata, retrolateral view [Gertsch, Platnick, 1975: f. 13]; b - same, prolateral [Ibid.: f. 14]; c-e - C. loricata, male \#035, tibia and tarsus of right palp, retrolateral, ventral and prolateral, respectively; $\mathrm{f}-\mathrm{h}-$ same for male $\# 037$, retrolateral, ventral and prolateral, respectively; i - C. loricata, male \#035, tibia and tarsus of right palp, frontal. Specimen \#037 lost most palp setae in the rehydration process.

Рис. 2. Пальпы самцов Cyclocosmia spp.: a - C. truncata, ретролатерально [Gertsch, Platnick, 1975: f. 13]; b - то же, пролатерально [Ibid.: f. 14]; c-e - C. loricata, самец \#035, голень и цимбиум правой пальпы, соответственно ретролатерально, снизу and пролатерально; $\mathrm{f}-\mathrm{h}$ - то же для самца \#037, соответственно ретролатерально, снизу аnd пролатерально; $\mathrm{i}-\mathrm{C}$. loricata, самец \#035, голень и цимбиум правой пальпы, вид спереди. Экземпляр \#037 утратил на пальпе покровные волоски в процессе регидратации.

(Fig. 3b), 034 - L:19/R:22 (Fig. 3c), 035 - L:22/R:21

(Fig. 3d) and 037 - L:25/R:25 (Fig. 3e); 219 (Fig. 3f), 250

(Fig. 3g) and 252 (Fig. 3h) have 21 ribs in both left and right side of the disc of the opisthosoma.

Male palp (Fig. 2c-i). Tibia (5.3-5.6) 3.5-3.7 times longer than the cymbium (1.4-1.6) and 2.9 times larger than the bulb (1.9); ventral aspect medially glabrous with large, thin setae in both margins, retrolateral aspect proximally glabrous with very sparse seta distally and prolateral aspect proximally glabrous and with small, very fine and sparse setae distally. Tarsus short with cymbium covered in short, thick setae; bulb 1.9 times larger than wide (1), somewhat globose, with a large, curved, tapering embolus which has a very slightly widened apex.

DISTRIBUTION. Cyclocosmia loricata was described from a specimen collected in Mexico without a specific state or locality being mentioned; since then it has been reported from the Mexican states of Guanajuato, Oaxaca (Santa Cata- rina Juquila), San Luis Potosí (west of Ciudad Valles and Sótano del Tigre), Tamaulipas (El Tinieblo andSótano del Refugio) and Veracruz (San Buenaventura) [Gertsch, Platnick, 1975]. With the new records given in this article the species is now also known from the state of Nuevo Leon (Fig. 4).

\section{Discussion}

Cyclocosmia truncata has been previously reported from the state of Nuevo Leon, Mexico [Solís-Rojas, Rodríguez-Tovar, 1995; Ruíz-Cancino, Coronado-Blanco, 2002], however, these records were based on misidentifications and refer to $C$. loricata. Accounting that records of $C$. truncata from Mexico are based on misidentification, this species can be currently considered as endemic of southeastern USA. 

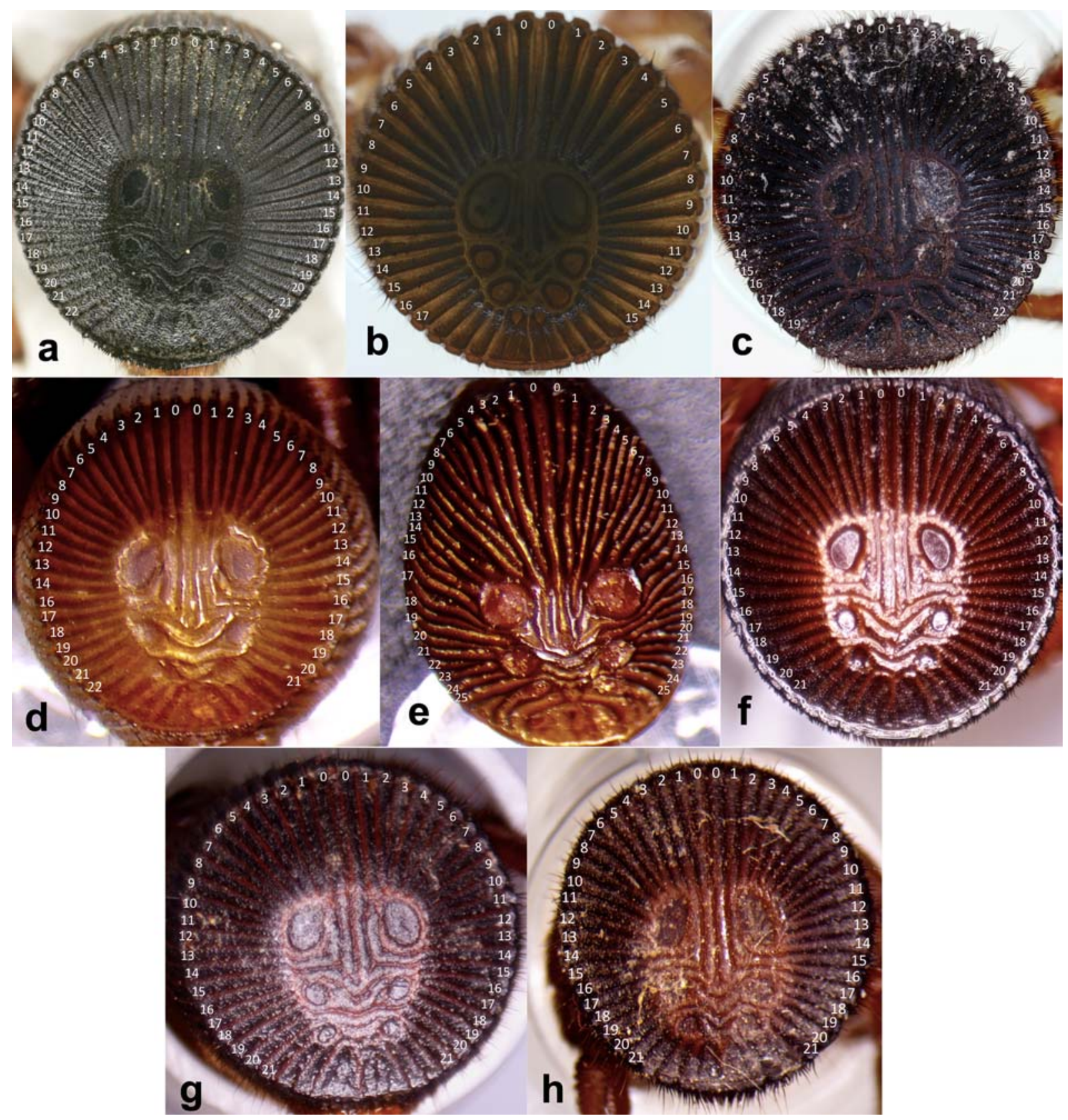

Fig. 3. Discs of the opisthosoma of $C$. loricata showing the rib counts: a - juvenile \#032; b - female \#033; c - female \#034; $d$ male \#035; e - male \#037 (rehydrated); f — juvenile \#219; g — female \#250; $\mathrm{h}$ — juvenile \#252.

Рис. 3. Брюшные диски C. loricata с индексацией числа ребер: а — ювенил \#032; b - самка \#033; с - самка \#034; $\mathrm{d}$ - самец \#035; е - самец \#037 (регидратирован); f — ювенил \#219; g — самка \#250; h — ювенил \#252.

Gertsch \& Platnick [1975] mentioned that the male palp of C. loricata showed no significant differences of that of the male $C$. truncata, however, we found that they are indeed different in the overall morphology as well as proportions.

Gertsch \& Platnick [1975] also mentioned that the rib count for C. loricata is varying from 18 to 20 ribs in either side of the disc, and that individuals from southern localities have more ribs than those which came from the north, despite this, the specimens from Nuevo
León showed the opposite by usually having more ribs than any of the previously known specimens (Fig. 3a, $\mathrm{c}-\mathrm{h}$ ). The specimen from Tamaulipas (Fig. 3b) also deviated from these counts in having the least ribs from any specimen known. This seems to indicate that the variation in rib count numbers is individual rather than clinal as previously theorized [Gertsch, Platnick, 1975].

Acknowledgments. We would like to thank doctorate student Daniela T. Candia Ramírez who helped us greatly 


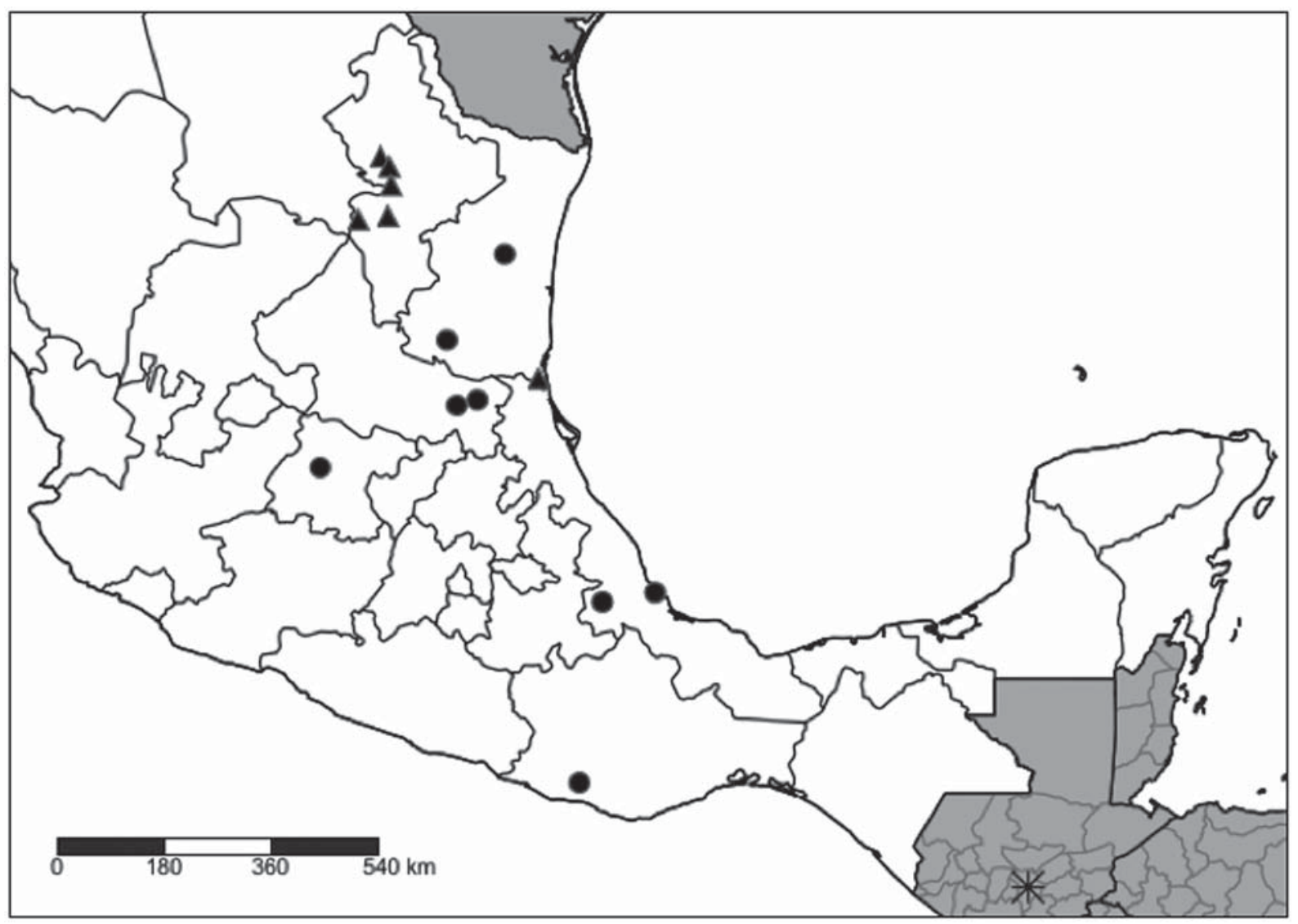

Fig. 4. Distribution of C. loricata including the previous (circles) and new (triangles) records.

Fig. 4. Распространение C. loricata, включая предыдущие (круги) и новые (треугольники) местонахождения.

with this article by reviewing it prior to being sent to the editorial team, as well as Dr. Yuri M. Marusik and the anonymous reviewers for their corrections, comments and recommendations.

\section{Compliance with ethical standards}

Conflict of Interest: The authors declare that they have no conflict of interest.

Ethical approval: No ethical issues were raised during our research.

\section{References}

Ausserer A. 1871. Beiträge zur Kenntniss der Arachniden-Familie der Territelariae Thorell (Mygalidae Autor) // Verhandlungen der Kaiserlich-Königlichen Zoologisch-Botanischen Gesellschaft in Wien. Bd.21. S.117-224.

Gertsch W.J., Platnick N.I. 1975. A revision of the trapdoor spider genus Cyclocosmia (Araneae, Ctenizidae) // American Museum Novitates. No.2580. P.1-20.

Gertsch W.J., Wallace H.K. 1936. Notes on new and rare American mygalomorph spiders // American Museum Novitates. No.884. P.1-25.

Godwin R.L, Opatova V., Garrison N.L., Hamilton C.A., Bond J.E. 2018. Phylogeny of a cosmopolitan family of morphologically conserved trapdoor spiders (Mygalomorphae, Ctenizidae) using Anchored Hybrid Enrichment with a description of the family, Halonoproctidae Pocock 1901 // Molecular Phylogenetics and Evolution. Vol.126. P.303-313.

Koch C.L. 1842. Die Arachniden. Nürnberg. Neunter Band. S.57108.

Petrunkevitch A. 1909. A trip to southern Mexico for spiders // American Museum Journal. Vol.9. P.249-256.

Ruíz-Cancino E., Coronado-Blanco J.M. 2002. Artrópodos terrestres de losestados de Tamaulipas y Nuevo León, México // Universidad Autónoma de Tamaulipas. Serie Publicaciones Científicas. 380 P.

Schwendinger P.J. 2005. Two new Cyclocosmia (Araneae: Ctenizidae) from Thailand // Revue suisse de Zoologie. T.112. P.225252.

Simon E. 1897. Note sur le Chorizopsloricatus C. Koch // Bulletin de la Société Entomologique de France. Vol.1897. P.172-173. Solís-Rojas C., Rodríguez-Tovar M.L. 1995. Listado preliminar de la fauna aracnológica del estado de Nuevo León // ContrerasBalderas S., González-Saldivar F., Lazcano Villareal D., Contreras-Arquieta A. (eds.). Listado preliminar de la fauna silvestre del estado de Nuevo León, México. Consejo Consultivo Estatal para la Preservación y Fomento de la Flora y Fauna Silvestre de Nuevo León. P.121-130.

World Spider Catalog. 2020. World Spider Catalog. Version 21.5. Natural History Museum Bern, online at http://wsc.nmbe.ch, accessed on $29^{\text {th }}$ November, 2020.

Xu X., Xu C., Li F., Pham D.S., Li, D.Q. 2017. Trapdoor spiders of the genus Cyclocosmia Ausserer, 1871 from China and Vietnam (Araneae, Ctenizidae) // Zookeys. Vol.643. P.75-85.

Responsible editor S.L. Zonstein 